\title{
21. Yüzyıl Becerileri Çerçevesinden Türk Atasözlerine Bir Bakış*
}

\section{Mehmet Kurudayıŏlu** \\ Nezir Temur ${ }^{* * *}$}

\section{$0 ̈ z$}

Bir toplumun evren tasavvuru, düşünce sistemi ve dünyaya bakış açısını ortaya koyan atasözleri, kolektif bilincin somut yansımalarıdır. Söz konusu dil hazinesi, aynı zamanda içinde var olduğu kültüre mensup bireyin sosyal hayatını düzenleyen birtakım öğretileri zaman ve mekân ötesine taşıma gibi bir işleve de sahiptir. Bu çerçevede içinde bulunduğu kültürün kodlarını aktarma işleviyle gelecek nesillere, davranış biçimlerini de öğütlemektedir. Bu çalışmada, Türk atasözleri çağımız modern insanından sahip olması istenen 21. yüzyıl becerileri (yaratıcılık ve yenilikçilik, eleştirel düşünme ve problem çözme, iletişim, iş birliği ) açısından incelenmiştir. Nitel araştırma desenlerinden durum çalışmasının kullanıldığı bu araştırmanın inceleme nesnesini, Nurettin Albayrak'in Türkiye Türkçesinde Atasözleri adlı eserinden alınmış 18837 atasözü oluşturmaktadır. Verilerin toplanmasında doküman incelemesi, çözümlenmesinde ise içerik analizi kullanılmışır. Çalışmanın sonucunda Türk atasözlerinde en çok eleştirel düşünme ve problem çözme becerisi üzerinde durulduğu tespit edilmiştir. Eleştirel düşünme ve problem çözme becerisini sırayla iletişim, iş birliği ve yaratıcılık becerileri izlemektedir.

\section{Anahtar Kelimeler}

Atasözü, eleştirel düşünme, yaratıcı düşünme, iletişim, iş birliği

Geliş Tarihi: 20 Mayıs 2020 - Kabul Tarihi: 03 Eylül 2020

Bu makaleyi şu şekilde kaynak gösterebilirsiniz:

Kurudayığlu, Mehmet ve Nezir Temur (2021). "21. Yüzyıl Becerileri Çerçevesinde Türk Atasözlerine Bir Bakış”. bilig - Türk Dünyası Sosyal Bilimler Dergisi 99: Dizgi sayfa no.

" Doç. Dr., Hacettepe Üniversitesi, Eğitim Fakültesi, Türkçe ve Sosyal Bilimler Eğitimi Bölümü - Ankara/ Türkiye

mkurudayioglu@hacettepe.edu.tr ORCID ID: 0000-002-0447-5236

*** Prof. Dr., Gazi Üniversitesi, Gazi Eğitim Fakültesi, Türkçe ve Sosyal Bilimler Eğitimi Bölümü - Ankara/ Türkiye 


\section{Giriş}

Her geçen gün yaşamın hemen hemen tüm alanlarında birçok değişim ve dönüşüm meydana gelmektedir. Örneğin teknoloji alanındaki bir yenilik, yeni bir gündelik yaşam pratiğinin doğmasına, bazı durumlarda birçok kişinin yaşamında önemli bir yer tutan bir günlük rutinin son bulmasına sebep olabilmektedir. Yeni bilgi üretmenin doğal bir süreci olan bu kolektif devinim ilkelden, postmodern toplumsal zihniyete kadar etkin bir şekilde varlığını sürdüregelmiştir. İnsan yaşamını etkileyen bu değişimler kuşkusuz bir gelişimdir ve tarihsel bir süreç özelliği gösterir. Bu, insanoğlunun bilgi ve tecrübelerinin kuşaklar arasında biriktirilerek aktarılmasının bir sonucudur.

Toplumlarda art zamanlı olarak tarihsel birikimin aktarılması, eş zamanlı olarak da toplumu oluşturan kişiler arasında anlaşmanın sağlanması dil ve söz varlığı aracilığıyla gerçekleşmektedir. Her toplum, dili ve söz varlığı aracıllğıyla kültür üretmekte ve yine aynı araçla kültürünü hem korumakta hem de yazılı veya sözlü olarak nesilden nesile aktarmaktadır. Bu işlevi ile dil toplumsal bir bellektir (Karadağ 2013a: 110). Sözel dile ait edebî verimler olması (Onan 2011: 91) dolayısı ile atasözleri de toplumsal belleğin çok önemli bir parçasıdır.

Atasözleri ait oldukları toplumun yaşayış tarzı, gelenek, görenek, örf ve âdetleri, olaylar karşısında takındıkları tutumlar, inançları, genel davranış örüntüleri, düşünme potansiyelleri, eleştiri kabiliyeti, dili kullanma becerisi, imge dünyasının genişliği, hadiseler hakkında akıl yürütme becerisi ve nüktedanlığı hakkında birçok bilgi verir (Aksoy 1995), (Mieder 2010). $\mathrm{Bu}$ açılardan bakıldığında atasözlerini gerek felsefi gerekse sosyolojik ve psikolojik bakımdan ortaya çıktığı kolektif bilincin bir kabulü olarak görmek mümkündür. Çünkü onlar, Toplumun ortak şuurunun oluşmasında, akıl, irade ve sezginin yaşantılardan süzdüğü insani birikim ve sosyal devinimin meydana getirdiği, halkın düşünce dünyasının izdüşümleridir (Baş 2012: 143).

Sözlü kültüre ait bir unsur olan atasözlerinin bellekte yer edinebilmesi açısından kısa ve özlü olması, kendine özgü bir söyleyişinin olmasını zorunlu kılmıştır. Kendine özgü formüle edilmiş dilsel yapısı dünyada farklı kültürlere ait atasözlerinin müşterek özelliğidir (Mac Coinnigh 2015). Bir dil evrenseli olarak da kabul edilebilecek bu özellik, atasözünün bellekte 
depolanmasını kolaylaştırdığından benzer problemlere veya olaylara uyarlanmasını da daha basit ve pratik hâle getirmiştir.

Düşüncenin özünü oluşturması sebebiyle toplumun ortak düşüncesi, atasözleri olmadan belirlenemez (Keser vd. 2013). Kolektif bilincin ürünü, yansıtıcısı ve taşıyıcısı olan atasözleri topluma ve bireylere yol gösterir, ortak anlamlar dünyası temin eder ve bu ortak anlamlar dünyasından hareketle algılama ve çıkarımlar yapma yetisi kazandırır (Biray 2016). Bu özelliğinden hareket ederek bireyler, atasözlerini bir düşünceyi veya bir hükmü desteklemek veya karşı çıkmak için kullanır (Başgöz 2006: 88). Bu sayede insan iddiasını desteklemek ve kanıtlamak için tanıklığı atalarının sözlerine bırakmış olur. Topluma özgü inanç, düşünce ve değerler sisteminin bir ürünü olması neticesinde atasözleri, meydana gelen olaylarda ve bireylerin birbirleri ile olan ilişkilerinde âdeta hüküm verici bir işlev üstlenmiştir.

Toplumların gelişimi ve değişimi yüzyıllardır devam etmektedir. Bu yolculukta atasözleri ister açı ister örtük olsun öğrenilmiş ve genel geçerlik kazanmış kurallar manzumesi olduğundan değişen dünyaya uyum sağlama çabasında olan insana sahip olması gereken nitelik ve yeterlikler konusunda kılavuzluk etmektedir. Çünkü atasözü sadece bir durumu özetleyen, geçmişteki bir meseleyi yargılayan değil aynı zamanda geleceğe yönelik bir eylem biçimini de öneren geleneksel bir söylemdir (Dundes 1975: 43).

Tüm toplumlarda önemsenen atasözleri, önemine binaen birçok kültürde farklı açılardan ele alınmakta ve tanımlanmaktadır (Başgöz 2006). Atasözleri üzerine yapılan çalışmalarda da bu çeşitliliği görmek mümkündür. Atasözleri, dil ve edebiyat (Altun 2004), (Gönen 2006), (Demircan 2005), (Onan 2011), (Güzel vd. 2013), (Mac Coinnigh 2015), (Tuğluk 2018); toplumbilim (Tüm 2010) (Akın 2010), (Erginer 2010), (Dik 2010) (Esen vd. 2011) (Rong 2013), (Karadağ 2013a), (Keklik 2013), (Beğenmez 2013), (Bekiroğlu 2014), (Biray 2016); eğitim (Örge Yaşar 2007), (Çakmakçı 2009), (Baş 2012), (Tekşan 2012), (Aydın 2013), Gürel vd. 2016), (Batur vd. 2019); psikoloji ve modern kuramları açısından (Van Lancker 1990), (Honeck vd. 1994), (Berger vd. 2005), (Keser vd. 2013), (Kurt 2012), (Karadağ 2013b) Mumford vd. 2018), (Dosi 2019) ele alınmakta ve bu anlamda bugünü ve geleceği yorumlamada kaynaklık etmektedir. $\mathrm{Bu}$ çalışmada modern hayatta bireylerin sahip olması beklenen becerilere atasözlerinin nasıl kaynaklık edebileceği ele alınmaktadır. 
Sürekli devinen ve gelişen modern hayatta, bireylerin yeni karşılaştıkları olaylar ve durumlarla baş edebilmeleri bazı becerilere sahip olmalarıyla mümkün olabilmektedir. Günümüzde insanlar hem okul hem de meslek hayatını kapsayan birtakım becerilere sahip oldukları oranda mensubu oldukları toplumda başarılı bir çizgide ilerleyebilmektedirler. Dede’ye (2010) göre 21. yüzyıl; insanların iş, vatandaşlık ve kendini gerçekleştirme için ihtiyaç duydukları kabiliyetlerde özellikle çok karmaşık bilgi ve iletişim teknolojilerinin ortaya çıkması nedeniyle 20. yüzyıldan oldukça farklıdır. $\mathrm{Bu}$ anlamda günümüz insanı 21. yüzyıl dünyasına ayak uydurabilmek ve başarılı bireyler olarak gerek kendine gerekse topluma fayda sağlayabilmek için birtakım donanımlara sahip olmalıdır. Bireylerin 21. yüzyıl istihdamında pay sahibi olabilmeleri için temel bilgi ve temel becerilerle edindikleri okul diplomaları yeterli olmamakta, sahip oldukları temel becerilerinin ötesinde, 21. yüzyıl becerileri olarak adlandırabileceğimiz bir dizi beceriye sahip olmaları gerekmektedir (Eryılmaz vd. 2015: 210). Bireylerin meydana gelen değişimlere uyum sağlaması veya tepki vermesi, teknolojiyi yakalayabilmeleri, hızla üretilen bilgi yığınları arasında bilgiyi seçerek, analiz ederek ve değerlendirerek elde etmeleri, elde ettikleri bilgiyi günlük yaşamlarında kullanabilmeleri ve ürüne dönüştürebilmeleri için temel becerilerinin yanı sıra üst düzey beceri ve yeterliliklere sahip olması gerekmektedir. Bilgi toplumunda bireylerin sahip olması gereken bu beceri ve yeterlilikler 21. yüzyıl becerileri olarak adlandırılmaktadır (Anagün vd. 2016: 161). Bu beceriler kendi içerisinde birbirleri ile bağlantılı olmakla birlikte yalnızca eğitim-öğretim ortamlarıyla sınırlı kalmayıp aynı zamanda yaşam boyu öğrenmeyi de kapsayan öğrencilerin okul ve meslek yaşamı için hazır olmasına yardımcı olan (Alismail vd. 2015: 154) beceriler bütünüdür.

P21'in (Partnership for 21st Century Learning) geliştirmiş olduğu çerçevede (Framework for 21st Century Learning) 21. yüzyıl becerileri yaşam ve kariyer becerileri; öğrenme ve yenilikçilik becerileri; bilgi, medya ve teknoloji becerileri olmak üzere üç ana grupta toplanmışır www.p21. org (Erişim Tarihi: 5 Haziran 2018). Öğrenme ve yenilikçilik becerilerini eleştirel düşünme, iletişim, iş birliği ve yaratıcılık becerileri oluşturmaktadır. Eleştirel düşünme boyutunda karmaşık problemleri analiz edebilme, açı ve net cevapları olmayan soruları araştırma, farklı bakış açılarını veya bilgi kaynaklarını değerlendirme, kanıtlara ve akıl yürütmeye dayalı uygun sonuçlara ulaşma (Ravitz vd. 2012: 3) bulunurken iletişim boyutunda ise 
sözlü, yazılı ve çeşitli dijital araçlarla etkili iletişim kurabilmenin yanında dinleme becerileri (Fullan 2013) yer almaktadır. Bu alanın diğer alt bileşeni olan iş birliği ise bilgiyi üretmek, kullanmak ve paylaşmak için diğerleriyle saygılı ve etkili bir şekilde çalışmak, çözümler sunarak yenilikler geliştirmek gibi birçok bileşeni kapsamaktadır (Trilling vd. 2012). Bu bölümün son becerisi olan yaratıcılık ise yeni ve faydalı fikirler üretme yeteneğidir (Sternberg vd.1999).

Türk atasözlerinde fert ve toplum ilişkileri, işbirliği, olaylar arasında neden-sonuç ilişkileri kurma, yeteneklerin değerlendirilmesi, evrensel ve toplumsal değerler, eğitim, iş ve zaman değerlendirilmesi, sosyal eleştiri gibi konular yaygın biçimde işlenmektedir (Boratav 1969). Tüm bu işlev ve özelliklerinden ötürü Türk atasözlerinin geçmişten geleceğe aktarılarak çağımız insanının sahip olması istenen temel becerilere ışık tuttuğu ve kaynaklık ettiği değerlendirilebilir.

21. yüzyıl becerilerinin diğer ülkelerde olduğu gibi Türkiye'de de eğitim politikaları doğrultusunda öğretim programlarında yer edinmesi ve Türkiye Yeterlikliler Çerçevesi'nde www.myk.gov.tr (Erişim Tarihi: 8 Mayıs 2020) vücut bulması, bu becerilerin hedef kültür açısından nasıl bir hazır bulunuşluğa iliştirileceği sorusunu gündeme getirmektedir. Bu açıdan Türk kültüründe bir eğitim politikası olarak yer edinen 21. Yüzyıl becerilerinin Türk kültürü içinde temel nitelikli bir kültürel gösterge ile ilintili olacak şekilde ele alınması, becerilerin Türk kültüründeki deneyimin çıtıları doğrultusunda oluşmuş kültürel potansiyele yönelik olarak eğitim ve öğretim ortamlarına aktarılmasında kaynak sağlayacak ve rehberlik edecektir. Türk kültüründeki deneyimin önemli bir göstergesi de atasözleridir.

Toplumun inşasında önemli rolü olan sözlü gelenek, bireyin toplumsallaşma sürecini bazı dilsel unsurlarla yansıtmaktadır. Bu yönde önemli bir yakın bağdaştırma olan atasözleri, toplumun ortak akıl ve yarg1 kültürünün göstergesi olarak ön plana çıkmaktadır. Birey, geçmişten bugüne uzanan sözlü kültür geleneğinin sosyal, psikolojik, folklorik bulgularının örüntüsü olan toplumsal davranış normlarını bazen doğrudan çoğu zaman örtük olarak atasözleri aracılığıyla tanımaktadır. Geçmişin birikimi olan atasözleri toplumun geleceğe yönelik hedefleri için potansiyel olma özelliği gösterir. Teknolojinin etkisiyle yaşanan ikinci sözlü kültür döneminde, toplumun öğrenme ve yenilikçi hedeflerini kestirebilme ve yordayabilme durumu, 
hâlihazırdaki kültürel potansiyelle yakından ilişkilidir. Özellikle 21. yüzyılın teknolojik getirileri doğrultusunda yapılanan çeşitli projeksiyonlar, "yaşam, kariyer, öğrenme, inovasyon (yenilikçilik), bilgi medya, teknoloji” gibi üst başlıklar altında değerlendirilmektedir. Bunlar arasında öğrenme ve yenilikçilik kategorisi altında ele alınan ve bireylerin sahip olması beklenen "eleştirel düşünme, iletişim, iş birliği, yaratıcıllı" gibi becerilerin nasıl kazandırılacağı sorunu ortaya çıkmaktadır. Bu açıklamalar doğrultusunda araştırmanın amacı; Türk atasözlerini, 21. yüzyıl becerileri çerçevesinde öğrenme ve yenilikçilik becerileri altında "eleştirel düşünme, iletişim, iş birliği, yaratıcılık” açısından sınıflamaktır. Yanı sıra halkın geçmişte deneyimlediği ve sözlü mirasla ortak bir akıl ve yargı özelliği kazandırdığı bu figüratif dil yapılarının gelecekteki toplumsal inşa sürecine potansiyel olarak nasıl kaynaklık edebileceğini tartışmaktır.

Yöntem

Bu araştırmada nitel araştırma desenlerinden durum çalışması kullanılmıştır. Araştırma bir durumda doğrudan belirmeyen ve derinlemesine incelenerek ortaya çıkan duruma dair birimleri keşfetmek (Yin 2017) amacıyla gerçekleştirildiği için keşfedici durum çalışması olarak yapılandırılmıştır. Araştırma durum çalışmalarında belirlenen "üç adım” (Yin 2017) doğrultusunda gerçekleştirilmiştir. Birinci adımda 21. yüzyıl becerilerinin eğitim ve öğretim ortamlarında aktarılabilirliğine dair kültürel bir potansiyel oluşturan Türk atasözlerindeki yer alma durumu belirlenmiştir. Türk atasözlerinin 21. yüzyıl becerileri açısından ortaya çıaracağ durum, alanyazın araştırmaları ve uzman görüşleri doğrultusunda 21. yüzyıl becerilerinden "öğrenme ve yenilikçilik” kategorisi ile sınırlanıp tek bir durum olarak ele alınmıştır. İkinci adımda durum çalışması desenin dört türünden iç içe geçmiş tek durum, araştırma deseni olarak belirlenmiştir. Öğrenme ve öğretme becerileri "yaratıcılık ve yenilikçilik (a. yaratıcı düşünme, b. başkalarıyla yaratıcı çalışma, c. yenilikleri uygulama) eleştirel düşünme ve problem çözme (a. etkili düşünme, b. sistem düşüncesini kullanma, c. yargılama ve karar verme, d. problemleri çözme), iletişim (a. açıç̧a iletişim kurma), iş birliği (a. başkalarıyla iş birliği yapma)," olmak üzere dört alt birimden oluşmaktadır. Bu birimler ve göstergeleri iç içe geçmiş bir özellik gösterdiği için çalışmanın ikinci adımında iç içe geçmiş tek durum deseni türü tercih edilmiştir. Araştırmanın üçüncü adımında 
belirlenen desen doğrultusunda kuramsal bir tarama yapılmış ve P21'in (Partnership for 21st Century Learning) 21. yüzyıl çerçevesi esas alınmıştır.

\section{Araştırmanın inceleme nesneleri}

Araştırmada 18837 adet Türk atasözü inceleme nesnesi olarak belirlenmiştir. Bu atasözleri Albayrak (2009) tarafından hazırlanmış "Türkiye Türkçesinde Atasözleri” adlı çalışmadan elde edilmiştir.

\section{Veri toplama araçları}

Çalışmanın veri toplama aracı doküman incelemesidir. Bu amaçla inceleme nesnesi olarak belirlenen tüm atasözleri Microsoft Excel'e satır satır aktarılmış ve her satırın karşısına "yaratıcılık ve yenilikçilik eleştirel düşünme ve problem çözme, iletişim, iş birliği” kategorilerinden oluşan dört basamak konulmuştur. Satırda yer alan atasözünün ilgili kategorilerden hangilerini içerdiğini belirlemek için iki uzman görevlendirilmiştir. Araştırmada durum tespitini yapan uzmanlar bu veri toplama aracına işaret koymuşlardır. Bu araçta yer alan kategorileri açıklayacak ve sınırlayacak göstergeler -yani bu kategorilerinin içeriklerinin sınılları- metin olarak uzmanlara sunulmuştur. Atasözlerinin açıklamaları da ayrı bir dosya olarak verilmiştir. Araşıımanın yürütücüleri de aynı araçlara işaretleme yaparak durum tespitinde bulunmuşlardır.

\section{Verilerin analizi}

18837 adet Türk atasözü 22 alan uzmanı ve 2 araştırmacı tarafından eş zamanlarda içerik analizi kullanılarak ayrı ayrı taranmıştır. 22 alan uzmanı iki gruba ayrılmış ve her grup tüm atasözlerini kendi içlerinde eşit sayıda paylaşarak incelemiştir. Bu şekilde alan uzmanlarının inceleyeceği atasözü sayısı nicel olarak sınırlanmıştır. Araştırmacılar ise tüm atasözlerini ayrı ayrı gözden geçirmiştir. Alan uzmanları ve araştırmacılar tarafından yapılan incelemelerde bu atasözlerinden 5290 tanesinde öğrenme ve yenilikçilik göstergelerinden en az birine rastlanmış ve bulgulamada bu atasözleri esas alınmıştır. Araştırmanın yürütücüleri kendi tespitlerini birleştirmiş ve ortak tespitler "1" rakamı ile işaretlenmiştir. İki ayrı uzmanın tespitleri de aynı şekilde birleştirilmiş ve ortak olan tespitler "1" rakamı ile gösterilmiştir. İki alan uzmanı ve araştırmanın yürütücüleri olan iki kişinin yaptıkları tespitler karşılaştırılmış ve alan uzmanları ile araştırmacılar tarafından yapılan ortak tespitler "2" rakamı, sadece uzmanlar veya araştırmacılar tarafından yapılan 
tespitler "1" rakamı ile belirtilerek bir tablo oluşturulmuştur. Bu şekilde "yaratıcılık ve yenilikçilik eleştirel düşünme ve problem çözme, iletişim, iş birliği” basamaklarını içeren Türk atasözleri belirlenmiş ve sayısal değerler betimsel analiz ile bulgulanmıştır.

\section{İnandırıcılık ve aktarılabilirlik}

Bu çalışmada inandırıcılık, aktarılabilirlik, tutarlılık, teyit edilebilirlik olmak üzere dört temel dış ve iç geçerlik unsurlarına ve tüm etik ilke ve süreçlere uyulmuştur. Türk atasözlerinde keşfedilmeye çalışılan 21. yüzyıl becerilerinden öğrenme ve yenilikçilik kategorisini oluşturan "yaratıcılık ve yenilikçilik eleştirel düşünme ve problem çözme, iletişim, iş birliği" basamakları ikiden fazla uzman ve araştırmacı ile taranarak üçgenleme sağlanmıştır. Veri toplama aracının geliştirilmesinde ve 21. yüzyıl becerilerinin araştırmanın amaçları doğrultusunda uzman görüşleri alınmış ve kuramsal çerçevede gerekli tanımlamalar yapılmıştır. Araştırmacılar kişisel varsayımlarını tarama ve değerlendirme sürecine dâhil etmemiştir. Araştırmada elde edilen bulgular, farklı araştırmalara kaynaklık edebilecek ve aktarılabilecek biçimde yapılandırılmıştır.

\section{Bulgular ve Yorum}

Araştırmada el edilen bulgular 21. yüzyıl becerilerinden öğrenme ve yenilikçilik kategorisinin dört basamağı doğrultusunda yorumlanmıştır.

\section{Türk atasözlerinde eleştirel düşünme ve problem çözme}

Bu kategoriye yönelik olarak 1441 atasözü tespit edilmiştir. 18837 toplam atasözü arasında çalışmaya esas alınan 5290 atasözünün \%27'sinde eleştirel düşünme ve problem çözmeye yönelik bir gösterge yer almaktadır. Atasözlerinde en fazla göstergenin yer aldığı kategori eleştirel düşünme ve problem çözme olmuştur. Yapılan içerik analizlerinde eleştirel düşünme ve problem çözme içeren atasözlerinin "etkili düşünme, sistem düşüncesini kullanma, yargılama ve karar verme, problemleri çözme” gibi göstergeler taşıdıkları tespit edilmiştir.

Etkili düşünmeye yönelik atasözlerinde duruma uygun çeşitli akıl yürütme türlerini (tümevarım, tümdengelim, analoji vb.) kullanmaya dair gönderme yapılır. Genelden özele dair çıkarımlar (Zelzeleyi gören, yangına razı olur.), özelden genele ulaşma (Yaş kesen, baş keser. Toprak avuçlayan, altın tutar.), 
benzeşmeden faydalanılarak yapılan öneriler (Yorganına göre ayağını uzat. Bir koltuğa iki karpuz sığmaz. Bir tahtta iki şah olmaz.), üçüncü hâlin imkânsızlığına dair saptamalarda bulunma (Ya bu deveyi gütmeli ya bu diyardan gitmeli. Ya devlet 'şahin' başa ya kuzgun leşe.), karşılaştırma aracılığıyla fikir oluşturma (Yılanın başı 'kafası' küçükken 'ezilir' ezilmeli. Yılanın başı dururken, kuyruğu ezilmez. Sabır acıdır, meyvesi tatlıdır. Ya aşını çanağına uydur ya çanağını aşına 'uydur'. Ya baltaya sap olmalı ya toprağa kürek.), ilişki kurma (Uğru yatağı, izinden bulunur.) vb. bunlara örnek gösterilebilir.

Sistem düşüncesini kullanmaya dair atasözlerinde, kişinin bir sistemin parçalarının bir şeyi başarmak için birlikte nasıl çalıştığını bilmesi gerektiğine vurguda bulunulur. Sistemin devamı için alternatifin önemi (Yedeğin kıymeti, bittiğinde belli olur.), sistemde etki düzeyi (Tayfa ne kadar çok olsa, iş geminin kaptanındadır.), sistemli düşüncede parça bütün ilişkisi (Taneyi harmanda, dalı ormanda ara. Takke ayağa, terlik başa giyilmez.), başarıya ulaşmada sistemli olma (Su aka aka yolunu bulur.) vb. çıkarımlar bu duruma örnektir.

Yargılama ve karar verme durumu içeren atasözlerinde kanıt, iddia ve inançları etkin bir şekilde analiz etme ve değerlendirme üzerinde yoğun biçimde durulur. Güç kullanmanın oluşturacağı adaletsizlik (Zor, oyunu bozar.), iş bilmezliğin sakıncaları (Yordamsız elin kazası çok olur. Yarım hekim candan eder, yarım fakih dinden eder. Ulumasını bilmeyen köpek, köye hırsız getirir.), doğru yargının önemi (Vara var, yoka yok denir.), bakış açısının göreceliği (Uğru kalana yanar, ev sahibi gidene.), dengenin önemi (Abdaldan paşa olmaz, kamıştan maşa olmaz. Ucuz etin çorbasını it içer. Ucuz etin suyu kara, yahnisi yavan olur. Ucuzun çorbası tatlı olmaz. Tuz ekmek hakkı bilmeyen, iki gözden olur. Şeker tatlıdır ama çuval ile yenmez. Şefkati olmayan, şefkat bulamaz.), emeğin etkisi (Tez biten, tez yiter. Saman olmayınca, somun olmaz. Öküzün kıymeti, yeri boşalanda belli olur.), liyakat (Tereciye (bostancıya) tere satılmaz. Ağlayan çocuktan iş beklenmez. Akıl için tarik (yol) birdir.), karar sürecinde aceleden uzak kalma (Son gülen, iyi güler.), doğru zamanı kollama (Soğuk demir dövülmez.), değer bilme (Sel gider, kum kalır; el gider, yâr kalır.), etki alanını doğru tayin etme (Saman pazarında mücevherin kıymeti olmaz.) vb. Önemli alternatif bakış açılarını etkili bir şekilde analiz etme ve değerlendirme yoluyla da yargılama 
ve karar verme üzerinde durulur. Çalışmanın üstünlügü (Oturan aslandan, gezen tilki yeğdir. Yük çeken eşek, boş gezen insandan iyidir.), imkânları amaçlı kullanma (Yersiz bahşiş, cömertlik sayılmaz.), çözüm bulma (Yağmur yağarsa saçak altından gidilir. Öç almak neyin işi, bağışlamak beyin işi.), bilginin öneminin farkında olma (Üç cahil dosttan, bir âlim düşman iyidir.), doğru aracı tercih etme (Saza saz ile söze söz ile karşı konur. Topal eşekle kervana karışma. Taş kafalı ile yarışa girme, yarılmasan da yorulursun.), yerini bilme (Şehirde tavuk olup gidaklamaktan, köyde horoz olup ötmek yeğdir.), beklemeyi bilme (Sarı saman, vaktinde (sarı) altın olur.), öz çıarımın önemi (Ne bulursan kendine bul, ne bilirsen kendinden bil. Nasihat istersen, komşunun ölümüne bak.) vb. Bu yönde bilgi ve argümanlar arasındaki bağlantıları kurabilme ve anlayabilmeye de değinildiği olur. Amaç araç ilişkisi (Abraş at yüke dayanmaz. Alet, sahibinin elinde işler. Astarsız yorgan, insanı 1sıtmaz.), tutarlılık (Ayna gibi, gördüğün renge boyanma.), donanım ögeleri (Baş büyük ama ayağa muhtaç.), öz farkındalık (Böğürtlen çiçek açmış, bağ oldum sanmış; yörük ata binmiş, bey oldum sanmış.) vb. Atasözlerinde yer yer bilgiyi görüp ve başarılı bir şekilde sonuç çıkarabilmeye de vurgu yapılır. Kestirim yapma (A ay oğlan, yarın doğru, yarın yalan. Ağıl ağıldan yüksektir, ta arşa varıncaya kadar. Arı kovanına çomak sokulmaz.), sorumluluk (Abacı, kebeci; sen neci?), planlı olma (Acele etmekle iş yol almaz. Ağır giden yol alır, hızlı giden yolda kalır.), amaçlılık (Ağrısız başa sakız yapıştırma. Arpa unundan kadayıf olmaz. Bitmeyecek yere tohum atılmaz.) denge oluşturma (Ağzın karnından büyük olmasın. Atın önüne et, itin önüne ot konmaz.), aklın önemi (Akıl değil yaşta, illa başta. Akıllı düşmandan korkma, deli dosttan kork. Akıllıyı arkada tutma, akılsızı (ahmağı) kılavuz etme.), emeğin karşılığı (Alından ter akmadan, cepten para taşmaz. Arpa eken, arpa biçer. Arpa verilmeyen at, kamçı zoru ile yürümez. Bağ dua değil, çapa ister.) tecrübenin değeri (Bir felaket, bin nasihatten evladır.) vb. Bazen de insandan öğrenme deneyimlerini ve süreçlerini eleştirel olarak yansıtmaları istenir. Zamanın tayini (Aba vakti aba alan, yaba vakti yaba alan yanılmamış.) farkındalık (Abdestime şüphem yok ki düşüneyim.), sabrın önemi (Acele bir ağaçtır (ki) meyvesi pişmanlık.), faydalı faydasız ayrımı (Ağlama ölü için, ağla deli için.), duygusal farkındalık (Aşkla akçe bir tutulmaz.) vb.

Problemleri çözme yönünde alışılmamış farklı problemleri hem geleneksel hem de yenilikçi yollarla etkin bir şekilde çözebilme üzerinde durulması 
gerekliliğine dikkat çekilir. Dikkatli olma (Zannetmediğin yerden tilki çıkar.), amaç-sonuç ilişkisi ( $\mathrm{Su}$, susamışa verilir. Üzümüm çok diyene, küfenin küçüğünü götürmeli. Yılanın başı dururken, kuyruğu ezilmez.), sebep sonuç ilişkisi (Verip de pişman olmaktan, vermeyip (de) düşman (pişman) olmak yeğdir. Yemeksiz yatmak, borçla kalkmaktan yeğdir. Yârdan bilme, Yaradan'dan bil.), hazırlıklı olma (Sakla samanı, gelir zamanı. Yağmur yağarken küpleri doldurmalı.), karar verme (Ya ağanın dediğini yapmalı, ya da kapısından gitmeli. Ulaşamadığın köyün berisinde yat. Tükürdüğün eli öpme.), çalışmanın karşllığı (Parayı veren düdüğü çalar. Vur çapayı, ye parayı. Üflemeyince, kaynar çorba içilmez.), öğrenmenin önemi (Öğrenmeye ar olmaz. Ne bulursan kendine bul, ne bilirsen kendinden bil.) vb. Bunun yanında farklı bakış açılarını netleştiren ve daha iyi çözümlere yol açan önemli soruları etkili bir şekilde belirleme ve sorular sormaya problem çözme açısından değinilir. Sonuca ulaşma (Allı yelek, pullu yelek; ama hani gömlek?), hedef oluşturma (Almazsın, satmazsın pazarda işin ne?), duyarlılık (Arsız adama söz neylesin, kokmuş ete buz (tuz) neylesin?), tutarlılık (Bu ne perhiz, bu ne lahana turşusu?) vb.

\section{Türk atasözlerinde iletişim}

Bu kategoriye yönelik olarak 489 atasözü tespit edilmiştir. Bu sayı, incelemeye esas alınan atasözlerinin yaklaşık \%11'ine karşılık gelmektedir. Değerlendirilen Türk atasözlerinde iletişime yönelik olarak beş farklı göstergede örneklere rastlanmaktadır.

Türk atasözlerinde iletişimi gerçekleştirmek için çeşitli biçimlerde ve bağlamlarda sözlü, yazılı ve sözsüz iletişim becerilerini etkin bir biçimde kullanarak düşünce ve fikirleri ifade etmeye gönderme yapılır. Dilin önemi (Dili kötü olanın, günü kötü. Dil adamı beyan eder. Adamın eti yenmez, derisi giyilmez; tatlı dilinden başka nesi var. Söz bir mermer taştır, yerini bulunca oturmalı.), anlamanın önemi (Anlayana sivrisinek saz, anlamayana davul zurna az.) sözde ekonomiklik (Az söyle, uz söyle.), alıcıya ulaşma (Ben senin karanlık yerde (karanlıkta) göz kırptığını ne bileyim?) dilin gücü (Bir söz ara bozar, bir söz ara dizer. Dil adamı vezir de eder rezil de. Dil, dilberden güzeldir.) iletişim ve insan ilişkisi (Değirmen iki taştan, muhabbet iki baştan.), iletişim çatışmaları ( Sen ben demeyince, değirmende kavga olmaz. Sözünü tartı ile söyle.) vb.

Bilgi, değerler, tutumlar ve niyetler de dâhil olmak üzere anlamı deşifre etmek 
için etkili bir şekilde dinleme yapılması gerektiğine dikkat çekilir. Gereksiz konuşmadan kaçınma (Ağzı çok işleyenin, kulağı bir seferde duymaz. Ağzın içinde tava vardır; lafı pişirip pişirip söylemeli. Akıllı söylemeden (önce) düşünür, akılsız düşünmeden söyler. Düşüne düşüne söyleyen, iş bitirir; düşünmeden söyleyen, baş yitirir. Sözün sarrafı ol, söyle; dinleyen olmazsa sükût eyle. Sözünü bil, pişir; ağzını der, devşir.) sözde ekonomiklik (Az söyleyen anılır, çok söyleyen yanılır.), dilde tecrübe (Büyüğe saygı, küçüğe sevgi atadandır.), dilin etki alanı (Dilin cirmi küçük, cürmü büyüktür. Diline sahip ol; dildir adamı yâr eder, dildir adamı yad eder. Elin ayıbını söyleyen, senin ayıbını da (seninkini de) söyler. Elin övdügünü al da kaç, kendini öveni koy da kaç.), iletişimde hazırlık (Sözü ağzında pişir, sonra çkar.) vb.

İletişimin farklı amaçlar için (bilgilendirme, talimat verme, motive etme ve ikna etme vb.) kullanılabileceğine yönelik değerlendirmelere yer verilir. Sebep sonuç ilişkisi (Ağız tetik, dil tüfek.), amaçlılık (Araya girersen çözmeye gir, bozmaya girme. Bir tutam ot, deveye hendek atlatır. Sözü söyle alana, kulağında kalana. Tatlı dil (kelam) dinletir, tatsız söz (kelam) esnetir. Tatlı dil (söz) yılanı deliğinden çıkarır.), karşılıklılık (Bana bir adım gelene, ben iki adım varırım. Bir acı kahvenin kırk yıl hatırı (hakkı) vardır. Bir dilim elmanın bin yıl hatırı var.) vb.

İletişimin etkilerinin nasıl değerlendirilmesi gerektiğine yönelik açılamalara da atasözlerinde yer verilir. Etki tepki durumu (Ağız var, inci döker; ağız var, zehir döker (söker). Ağızdan çıkan, başa değer.), değer belirleme (Armut sapından, insan dilinden tutulur. Az sözden çok şey çıkaran, insandır. Değirmeni su döndürür, insanı dil. Üslub-u beyan, ayniyle insan.), dilin etki düzeyi (Bıçak yarası geçer, dil yarası geçmez. Söz birliği, el birliği.) vb.

Çeşitli ortamlarda etkili iletişim kurmaya yönelik örneklere de atasözlerinde rastlamak mümkündür. Toplumsal seviyede dilin etkisi (Adamın ağzına bakarlar, atına ona göre nal çakarlar.), iletişimde doğru zaman (Akşamdan sonra safa, hoş geldin Ağa Mustafa.), hedef kitleyi tanıma (Ben derim bayram haftası, o anlar mangal tahtası. Ben sorarım ilm-i hikmetten (hikmet ilmi), sen dersin çalmadım kilimi mektepten. Eli uzundan, dili uzundan sakın. Elin övdüğünü al da kaç, kendini öveni koy da kaç.), doğru söylemenin gücü (Doğru sözde ayıp olmaz.), sözün gücü (Söz var, dağa çıkarır; söz var, dağdan indirir. Söz var, gelir geçer; söz var, deler geçer.) vb. 


\section{Türk atasözlerinde iş birliği}

Bu kategoriye yönelik olarak 201 atasözü tespit edilmiştir. Araştırmada incelemeye alınan Türk atasözlerinin yaklaşık \%3'ünde iş birliğine gönderme yapıldığı görülmektedir. İş birliğine yönelik atasözlerinde üç farklı göstergeye yönelik örnekler tespit edilmiştir.

Farklı takımlarla etkili ve saygılı bir şekilde çalışabilme yeteneğinin gösterilmesine dikkat çekilir. Diğer tecrübelerden faydalanma (Akıl, akıldan üstündür.), diğer insanların desteğini alma (Arkanı ya bir dağa ver ya bir beye. Dört göz, ikiden farklı görür.), ortak güç oluşturma (İş, elbirliğiyle olur biter.), hazırlık yapma (Kedi beslemeyen, fareleri besler.), tek başınalığın zorlukları (Yalnız taş, duvar olmaz. Yalnız kalanı kurt yer. Yalnız kuş yuva yapmaz. Ağaç, dalıyla gürler.) vb.

İşbirlikçi çalışma için paylaşılan sorumluluğun üstlenilmesi ve her takım üyesinin bireysel katkılarına değer verilmesi üzerinde de yer yer durulur. Birliğin önemi (Ağaç ağaca çatılarak yapı yapılır. Adam adama gerek olmasa, her biri bir dağ başında olur. Arka, düşman göre korka. Bir el, bir eli (el eli) yıkar; iki el (de) bir yüzü yıkar.), yardımsever olma (Çakmak karataştan, iyilik iki baştan.) vb.

\section{Türk atasözlerinde yaratıcılık}

Bu kategoriye yönelik olarak 54 atasözü tespit edilmiştir. Sınırlı sayıda atasözünde rastlanan yaratıcılık kategorisinde yaratıcı düşünmek, başkaları ile yaratıcı çalışmak, yenilikleri uygulamak göstergelerine rastlanmaktadır.

Yaratıcı düşünmek için fikir yaratma tekniklerini kullanmaya ve fikir sunarak katılımcı olmaya örnek, atasözlerinde oldukça sınırlıdır. Çözüm bulmada olumsuz uyaranlar (Açlık adama (ayıya) oyun öğretir.), emek harcama (Şans gökten zembille inmez. Var, adama oyun öğretir. Yaz, bereketi kıştan alır.) vb.

Mevcut ve yeni bilgilerin yanı sıra mevcut ve yeni kaynakları kullanarak yeni ve değerli fikirler geliştirmeye vurgu yapıldığı da olur. Fikir üretme becerisi (Aklı başında olan, eşeğini dağdan taştan indirir.), seçenek bulma (Su bulunmayan yerde teyemmüm caizdir.), kararlı olma (Utananın oğlu, kızı olmamış. Yaman baş sahibine domuz güttürür.) vb.

İnsanın kendi fikirlerini yansıtması ve çalışmalarının değerini artırmak için yaratıcı çabalardaki değişiklikleri sürece dâhil etmesine de gönderme 
yapılır. Yeteneği kullanma (Elde istidat olunca, iş kendini gösterir. Teptim keçe, büzdüm külah; giy şimdi başına.), iş farkındalığı (Üzümcünün gözü omçada olur. Yola çıkan yol alır, erken evlenen döl alır.) vb.

Yaratıcılık gösterme ve durumun sınırları hakkında gerçekçi olmaya değinilir. Farkındalık (Arı, bal alacak çiçeği bilir.), çaba (Tuzağa yakalanan kuş, elbette çırpınır.), hazırlıklı olma (Uğradığın çayın geçidini ara. Yağmurda korkan tilki, bir kulübecik yapar.) vb.

Yenilikleri uygularken işlere gerçek ve faydalı bir katkı sağlamak için yaratıcı fikirleri uygulamanın önemi ön plana çıkar: Özgünlükte çaba (Arı, balın etrafından dolaşır. Güçlük içinde bir kolaylık bulunur. Ummadığın itten kırk batman yağ çıkar. Ummadığın keçiden bir batman yağ çıkar.), kaynak belirleme (Vakti ganimet bilmek gerek.) vb.

\section{Tartı̧̧ma ve Sonuç}

Geçmiş zamanın bilgi, deneyim ve birikimini bugüne ve geleceğe taşıyan atasözlerinde geleceğe yönelik ön görülerin araştırıldığ kapsamında 18.837 Türk atasözü 21. yüzyıl insan profilinde bulunması beklenen öğrenme ve yenilikçilik becerileri (eleştirel düşünme ve problem çözme, iletişim, iş birliği ve yaratıcılık) perspektifinden ele alınmıştır. Çalışmanın sonucunda Türk atasözlerinde en çok eleştirel düşünme ve problem çözme becerisinin üzerinde durulduğu tespit edilmiştir. Eleştirel düşünme ve problem çözme becerisini sırayla iletişim, iş birliği ve yaratıcılık becerileri takip etmektedir.

Sınama-yanılma yoluyla edinilen tecrübelere dayalı olan ve toplumsal belleğin analitik düşünme yetisinin örneklerini teşkil eden atasözleri Türk insanına eleştirel düşünme ve problem çözme becerisinin uzantısı olan akıl yürütme konusunda kayda değer oranda yönlendirme yapmaktadır. Benzer durum diğer toplumların atasözlerinde de mevcuttur. Çünkü atasözleri doğduğu toplumun bilgeliğini, deneyimlerini, dünya görüşünü ve düşünce yapısını ortaya koyan kültürel ürünleridir. Hatipoğlu’na (1972, Örge Yaşar 2007'den) göre her ulusta atasözlerine rastlanılması insanların daima geçmiş kuşakların düşünce ve denemelerinden yararlanmak istediklerini, ihtiyaç karşısında atalarının akıllarına, ögütterine başvurduklarını gösterir. Türk atasözlerinde akıl yürütmenin çeşitli yolları somutlaştırılarak ortaya konulmuştur. 
Berger vd. (2005: 195-221) yapmış oldukları uygulamalı çalışmayla atasözlerinin insanlarda düşüncenin uyanmasını sağlayan önemli bir araç olduğunu ortaya koymuşlardır. İçinde barındırdığı yüzeysel anlatımlarla atasözleri insan zihninde çağrışımlara vesile olurken sahip olduğu sembolik anlatımlarla da insanların eleştirel ve yaratıcı fikirler üretmesine ön ayak olmaktadır. Türk atasözleri de düşünce üretme ve akıl yürütmeyi kılavuzlaması açıdan oldukça zengindir. Genelden özele, özelden genele, benzeşme, karşılaştırma, ilişki kurma gibi yöntemler atasözleri içinde farklı örnek yaşantılarla gösterilmiştir. Benzer şekilde eleştirel düşünmede önemli bir basamak olan alternatif çözüm, parça bütün ilişkisi ve etki düzeyi gibi alanlar; yargı ortaya koyma ve karar verme sürecinde adalet, iş bilmenin önemi, doğru yargı, bakış açısında çeşitlilik, denge, emek, liyakat, sabır, zaman yönetimi, değer vb. etkenler; yargılamada analiz ve değerlendirmeye yönelik olarak sunulan çalışmanın önemi, amaçlılık, çözüm üretme, doğru aracı tercih etme, potansiyel, öz çıkarım vb. uyaranlar; bilgi ve argümanlar arasındaki bağlantının oluşturulmasında amaç araç ilişkisi, tutarlılık, donanım, öz farkındalık; bilgi temelli sonuca varma sürecinde kestirim, sorumluluk, planlılık, amaçlılık, denge, akıl, emek ve tecrübenin rolü; deneyimin eleştirel yönde yansıtımında zaman tayini, farkındalık, sabır, fayda, duygusal farkındalık, emek ve sorumluluk Türk atasözlerinin eleştirel düşünme ve problem çözme istikametindeki yoğun ve doygun potansiyelinin önemli göstergeleri olarak gözükmektedir.

Atasözleri bireyin her zaman karşılaşabileceği, zaman içinde tekerrür edebilen problemlere sosyokültürel açıdan çözüm öneren ifadeler içermektedir (Çobanoğlu 2004). Kurt (2012), atasözlerinin algılamanın, disiplinin ve sınama-yanılma yoluyla öğrenme ve öğretmenin örneklerini içerdiğini ortaya koyarak; bireyin akıl ve mantığına seslenmesi sebebiyle Türk toplumunca kabul gören mutlak yol göstericiler olduğunu belirtmiştir. Biray da (2016) benzer şekilde, Türk atasözlerinin sebep-sonuç ilişkilerini irdeleyen çözümleyici bir yapıya sahip olması dolayısıyla çözüme yönelik işleyişlerinin tartışmasız olduğunu vurgulamıştır.

Ortaya konulan özellikler atasözlerini eleştirel düşünme ve problem çözme becerisiyle yakından ilişkili kılmaktadır. Bilindiği üzere eleştirel düşünme, karşılaşılan bilgi ve problemlerin akıl yürütme ve mantığın etkin bir şekilde kullanılarak, dikkatle sınanmasını kapsar (Çakmakçı 2009). Batur vd. (2019) 
atasözlerinin sosyal yaşamın izleri ve birikiminden hareketle karşılaşılan bir problemin nasıl sorgulandığı ve çözüldüğü hakkında bilgi verdiğini belirterek atasözleriyle eleştirel düşünme arasındaki ilişkiyi vurgulamıştır. Bir başka deyişle araştırmacılara göre atasözlerinde problemler karşısında yapılan akıl yürütmeler ve problemlere yönelik getirilen çözüm önerileri analitik ve eleştirel düşünmenin bir ürünüdür.

Atasözlerinin gerisinde yer alan analitik düşünme ve akıl yürütme yoluyla edinilmiş uzun soluklu birikim ve tecrübelerin Türk insanının kolektif bilincinde nesilden nesle taşınarak bireylerde eleştirel düşünme ve problem çözme becerisine yönelik bir alt yapı oluşturduğu söylenebilir. Bu alt yapının Türk insanının asırlar süren uzun gözlemlerine, denemelerine ve mantığına dayalı olduğunu gözden uzak tutmamak gerekir.

İletişimin sosyal ve gündelik yaşamdaki etkisi açısından önemli sayıda örneği barındıran Türk atasözlerinde sözlü ve yazılı iletişim becerilerinin etkin kullanımına vurgu yapılmakla birlikte dilin önemi, iletişimde anlamanın gerçekleştirilmesi, sözde ekonomik davranma, alıcıya ulaşma noktalarında önemli değerlendirilmeler yapılmış, dilin gücüne ve insan ilişkilerindeki rolüne ve iletişim çatışmalarının sebeplerine de değinilmiştir. Etkili dinlemede gereksiz konuşmalardan kaçınma, ekonomik söz tercihi, tecrübenin önemi ve dilin etki alanı yanında iletişimde hazırlığın gerekliliğine yönelik önemli yargılar da ortaya konmuştur. Ayrıca iletişimin sebep sonuç, amaçlılık, karşılıklılık gibi uyaranlarla iletişime yön verilmesi gerektiğine; iletişimin değerlendirilmesinde etki tepkinin gözetilmesi, değer farkındalı̆̆ı ve söz vermenin önemine de vurgu yapılmıştır. Atasözlerinde farklı ortamlara ait etkili iletişim örnekleri dile getirilmiştir. Bu tespitler, Türk atasözlerinin bireyin sosyal dünyasında etkili iletişim kurmasının önemine katkı sağlayacak önemli deneyimleri içerdiğini göstermektedir.

Kolektif bilincini sırtlanan, dil aracıllğıyla görünür kılan, geçmişten bugüne ve geleceğe birtakım mesajlar iletme amacı güden atasözlerinin doğası gereği iletişimle iç içe olduğunu söylemek mümkündür. Atasözleri yüzyıllar içinde aynı dili konuşan kişiler arasında kültürün aktarılmasına zemin oluşturarak bir iletişim ortamı yaratılmasına yol açmaktadır (Çalışır 2016: 93). Bekiroğlu (2014) atasözlerinde bir toplumun genel anlamda iletişime ve iletişim edimlerine ilişkin bakış açısını yansıtan gönderimlerin gömülü olduğunu; dolayısıyla bir toplumun iletişimsel açıdan anlam haritasını çıkarabilmek için 
o toplumun folklor ürünü olan atasözlerinin irdelenmesinin bir gereklilik olduğunu ifade etmiştir. Onan (2011), Türk atasözlerinde dil farkındalığı ve işlevsel dil kullanımını incelediği araştırmasında atasözlerindeki mesajların ağırlıklı olarak konuşma becerisiyle ilgili olduğunu; sükût kavramının, az konuşup çok dinlemenin Türk atasözlerinde bilgeliğin bir işareti olarak dile getirildiğini; atasözlerinde sözün insanlar üzerindeki olumlu ve olumsuz etkilerine yönelik mesajların verildiğini tespit etmiştir. Buna paralel olarak Bekiroğlu (2014) da Türk atasözlerinde özellikle sözün niteliği, söz söyleme, daha çok dinleme ve daha az konuşmaya yönelik vurguların olduğunu tespit etmiştir. Çalışır (2016), Türk atasözlerinde söz söyleme, konuşmadinleme, dostluk-arkadaşlık, dış görünüş ve yazı yazmaya vurgu yapıldığını tespit etmiş; konuşma ve dinleme üzerine söylenmiş atasözlerinin sayısal olarak diğer başlıklar altında söylenenlerden daha fazla olduğu bulgusuna ulaşmıştır. Gürel vd. (2016), atasözleri ve deyimlerde bir iletişim edimi olarak dinleme temasını araştırdıkları çalışmalarında benzer olarak Türk atasözlerinde dinleme eylemi ile ilgili kavram ve eylemlerin yoğun olarak kullanıldığını ortaya koymuşlardır.

Kısacası atasözlerinin bir toplumun iletişimsel davranışlarına yönelik ipuçları taşıyan birer iletişim aracı olduğu ve aynı zamanda bunların ortak bir toplumsal ve kültürel paradigmaya yönelik referanslar taşıdığı söylenebilir (Bekiroğlu 2014). Türk atasözlerinde Türk toplumunun kişilerarası iletişime bakış açısının yansıtıldığı, etkili dinlemeyi ve düşünerek konuşmayı önceleyen bu bakış açısının günümüz dünyasının iletişimsel ihtiyaçlarına hitap ettiği düşünülebilir.

Atasözlerinde vurgulanıp öğütlenen bir başka değer birlik ve beraberliktir. Atasözlerindeki bu birlik ve beraberlik vurgusu 21. yüzyıl becerileri olan girişimcilik ve iş birliği ile ilişkilendirilebilir. Harbi vd. (2018), girişimci kişilerde bulunması gereken niteliklerden biri olarak iş birliğine ve ekip çalışmasına yatkınlığı göstermişlerdir. Türk atasözlerinde iki kişi arasındaki birlikten millet düzeyindeki birliğe kadar bütün birlikteliklerin gerekliliği vurgulanırken ayrılığın ve yalnızlığın olumsuz sonuçları hatırlatılmıştır (Beğenmez 2013). Dolayısıyla Türk atasözlerinde günümüz insan profilinde bulunması beklenen girişimcilik ve iş birliğine ve ekip çalışmasına yatkınlık becerilerine yönelik ön görülerin bulunduğu söylenebilir. 
Akın (2010), dayanışma olgusunun dikkate alındığı atasözlerinde ortak akıl oluşturma süreçlerinin önemsendiğini belirtmiştir. Beğenmez (2013), iş birliğinin uzantısı olan yardımlaşmanın işleri kolaylaştıracağının atasözlerimizde vurgulandığını ifade etmiştir. Girmen (2013), Türkçe derslerinde değer eğitimi amaçlı olarak kullanılabilecek atasözlerini araştırdığı çalışmasında en çok dayanışma değerine ilişkin atasözleri tespit edildiğini belirtmiştir. Küçük (2015), atasözlerinde ortak hareket etmeyle ilgili hem olumlu hem olumsuz ifadelerin yer aldığını, bazı atasözlerinde ortaklığa bazılarında ise kendi başına hareket etmenin daha doğru olacağına vurgu yapıldığını belirlemiştir. Araştırmacı atasözlerinde birlik ve ortaklığın değerli olduğuna fakat ihtiyatlı yaklaşılması gerektiğine yönelik mesajların yer aldığını tespit etmiştir. Gönen (2006), toplumsal yaşantının en önemli dinamiklerinden olan birliktelik ve yardımlaşmanın Türk atasözlerine yansıdığını, bu durumun Türk toplumunda bu değerlere bağlllığı işaret ettiğini belirtmiştir. Harbi vd. (2018) Türk atasözlerinde iş birliğine ve ekip çalışmasına yönelik mesajların yer aldığını ancak ekip çalışmasına yatkınlığa yönelik atasözlerinin nispeten daha az olduğunu belirtmişlerdir.

Türk atasözlerinde diğer kategorilere göre daha sınırlı da olsa iş birliğinin önemine yönelik olarak takım kurmada girişimcilik açısından tecrübeden faydalanma, destek alma, ortak güç, tek başınalıktan kaçınmaya yönelik yargılara; ortak bir hedef ve uzlaşma açısından dirlik, paylaşma ve insan kazanmanın rolüne; sorumlulukta bireysel katkı açısından birlik ve yardımseverlik bilincine yönelik yargılara rastlanılmıştır. Bu durum Türk insanının sosyal yaşam alanındaki tecrübelerinde iş birlikçi eyleminin göstergesi olarak görülebilir.

Karşılaşılan problemlere geleneksel çözümlerin tersine özgün ve yeni çözümlerin ortaya konulması (Mumford vd. 2018: 147) olan yaratıcılık bir düşünme stilidir. Yaratıcı ve eleştirel düşünen bireylerin yetiştirilmesi toplumun sağlıklı gelişimi açısından hayati öneme sahip bir konu olarak atasözlerine de yansımıştır (Örge Yaşar 2007). Atasözlerimizin bir kısmı bireyin yaşam felsefesinde doğrudan yaratıcı düşünme becerisini geliştirirken yaşamda var olan her türlü ögeyi kullanarak atasözü kalıplarını oluşturmak da yaratıcı düşüncenin bir belgesi şeklinde Türk kültürünün gücünü göstermektedir (Çakmakçı 2009: 23). 
Türk atasözlerinin insanları yaratıcı davranmaya yönlendirmesine yönelik göndermeleri çok sınırlıdır. Bu doğrultuda olumsuz uyaran ve emeğin çözüm bulmada yaratıcılığı kolaylaştırmasına; fikir üretme, seçenek oluşturma ve kararlılığın yeni ve değerli fikirler oluşturmadaki önemine; yetenekleri kullanma ve iş farkındalığı kazanmanın yaratıcıllğı etkilemesine; uyumlu olma ve doğru kestirimlerde bulunmanın yaratıcı yeteneği ön plana çıkarmadaki rolüne; farkındalık, çaba ve hazırlıklı olmanın yaratıcılıktaki gerçekçiliğine; denemenin ve özgünlükte çaba göstermenin yaratıcılıktaki etkisine rastlanmıştır. Bu veriler de Türk insanının yaratıcılık konusunda girişimci olduğunun kanıtı olarak değerlendirilebilir. Esen vd. (2011) Türk atasözlerinin girişimciliğe yönelik olarak hem olumlu hem de olumsuz iletiler barındırdığını, olumlu olanların olumsuzlardan daha fazla olduğunu belirtmişlerdir.

Başarılı bir girişimcide bulunması gereken özelliklerden biri olarak işaret ettikleri yaratıcılık ve yenilikçilik becerisiyle ilgili olarak Harbi vd. (2018) da sınırlı sayıda atasözü tespit etmişlerdir. Araştırmacılar bunun sebebi olarak Türk toplumunda yaratıcıllğın çoğunlukla marjinal olarak nitelendirildiğini, geçim derdinin ön planda olması sebebiyle olağan olanın yüceltilmesinin bir savunma mekanizması olarak kabul edildiğini göstermişlerdir.

Türk toplumunun düşünce sistemini ve dünyaya bakış açısını ortaya koyan atasözleri gerek geçmişimizde gerek bugünümüzde gerekse geleceğimizde karşılaştığımız ve yeniden karşılaşabileceğimiz durum ve problemlerin karşısında gerçekleştirmemizde yarar olan tutum ve davranışları -kolektif akla dayanarak- öğütlemiştir ve öğütleyecektir. Atasözleri kökleri mazide olsa da daima âtiden beslenir ve âtiyi besler. Bu sebeple atasözlerinin hem günümüz koşullarına göre değişim ve dönüşümünü izleme hem de güvenilir bir başvuru kaynağı olarak onlardan yararlanma imkânı bulunur. Bu çalışma kapsamında atasözlerimizde 21. yüzyıl ihtiyaç ve değerlerine yönelik ön görülerin izlerine rastlanılması Türk toplumunun ileri görüşlülük meziyetine işaret eder niteliktedir. $\mathrm{Bu}$ anlamda denilebilir ki Türk toplumunun kolektif bilinci 21. yüzyıl becerileri olan öğrenme ve yenilikçilik becerilerinin kazanılması ve uygulamaya dökülmesi için gereken ön hazırlığa sahiptir. Eleştirel düşünme ve problem çözme, iletişim, iş birliği ve yaratıcılık becerileri Türk toplumu için yeni duyulan, Türk toplumunun tamamen yabancı olduğu beceriler değildir. Türk eğitim sisteminin bu 
kültürel hazırlık kaynağından beslenerek geliştirilmesi 21. yüzyıla hazır, yüzü geleceğe dönük bireylerin yetiştirilmesi için bir gerekliliktir. Atasözleri yalnızca yeri geldiğinde söylenmek ve yazılı ve sözlü anlatımı güçlendirmek için değil Türk toplumunun tecrübelerini, düşünce yapısını ve geleceğe hazırlanırken heybesinde hâlihazırda var olan değerlerin analiz edilebilmesi açısından da değerlidir.

\section{Kaynaklar}

Akın, Adnan (2010). "Kültür Penceresinden Türk İş Sisteminin Temelleri ve Atasözleri Bağlamında Bir Model Önerisi”. Uluslararası İnsan Bilimleri Dergisi 7 (2): 809-838.

Aksoy, Ömer Asım (1995). Atasözleri ve Deyimler Sözlïğü. Ankara: İnkılâp Yayınları. Albayrak, Nurettin (2009). Türkiye Türkçesinde Atasözleri. İstanbul: Kapı Yayınları. Alismail, Halah Ahmed ve McGuire, Patrick (2015). "21st Century Standards and Curriculum: Current Research and Practice". Journal of Education and Practice 6 (6): 150-155.

Altun, Mustafa (2004). "Türk Atasözleri Üzerine Sentaktik Bir İnceleme”. Akademik Araşttrmalar Dergisi 6 (21): 79-91.

Anagün, Şengül Saime vd. (2016). "Öğretmen Adaylarına Yönelik 21. Yüzyıl Becerileri Yeterlilik Algıları Ölçeğinin Geliştirilmesi: Geçerlik ve Güvenirlik Çalışması”. Pamukkale Üniversitesi Eğitim Fakültesi Dergisi 40: 160-175.

Aydın, Seçkin (2013). "Kültürel Bir Miras Olarak Atasözlerinin Kullanımı Üzerine Türkçe Öğretmenlerinin Görüşleri”. Folklor/Edebiyat 19 (75): 173-192.

Baş, Bayram (2012). "Atasözlerimizde Düşünceyi Geliştirme Yolları". VII. Uluslararası Büyük Türk Dili Kurultay Bildirileri. Ankara: Uzerler Matbaacılık Ltd. Şti.

Başgöz, İlhan (2006). "Atasözleri Hakkında Atasözleri ya da Atasözlerinin Toplumsal Anlamı”. Çev. Toçoğlu, N. T. Millî Folklor 70: 85-91.

Batur, Zekerya ve Mehmet Soyuçok (2019). "Atasözlerinde Eleştirel Düşünme Unsurları: Türkçe Ders Kitapları”. Folklor/Edebiyat 25 (100): 1119-1130.

Beğenmez, Nuh Mustafa (2013). Atasözlerinde Günlük Hayat. Yüksek Lisans Tezi. Afyonkarahisar: Afyon Kocatepe Üniversitesi.

Bekiroğlu, Onur (2014). "Türkçe Atasözlerinde İletişim Olgusunun İzleri ve SosyoKültürel Çıkarımları”. Millî Folklor 103: 80-98.

Berger, Jonah A. ve Heath, Chip (2005). "Idea Habitats: How the Prevalence of Environmental Cues Influences the Success of Ideas". Cognitive Science 29: 195-221.

Biray, Nergis (2016). “Türk Dünyasının Ortak Değeri Olarak "Akıl” Konulu 
Atasözleri”. Türk Kültürü̈ ve Hacı Bektaş Velî Araștrma Dergisi 81: 133-150. Boratav, Pertev Naili (1969). 100 Soruda Türk Halk Edebiyatı. İstanbul: Gerçek Yayınları.

Bozkurt, Şeyma Büşra ve Çakır, Hasan (2016). "Ortaokul Öğrencilerinin 21. Yüzyıl Öğrenme Beceri Düzeylerinin Cinsiyet ve Sınıf Seviyesine Göre İncelenmesi”. Pamukkale Üniversitesi Ĕ̆itim Fakültesi Dergisi 39: 69-82. Çakmakçı, Celal Can (2009). İlköğretim İkinci Kademe Türkçe Öğretiminde Kavram Geliştirme Açısından Atasözü ve Deyimler. Yüksek Lisans Tezi. Zonguldak: Karaelmas Üniversitesi.

Çalışır, Gülsüm (2016). "İletişim ve Kişilerarası İletişim Alanında Söylenen Atasözleri Üzerine Bir Analiz”. International Symposium Culture and Communication in Anatolia: Past, Present and Future. Ankara: Atılım Üniversitesi Yay. 92-108.

Çobanoğlu, Özkul (2004). Türk Dünyası Ortak Atasözleri Sözlü̈̆̈̈. Ankara: Atatürk Yüksek Kurumu Atatürk Kültür Merkez Yayınları.

Dede, Chris (2010). "Comparing Frameworks for 21st Century Skills". 21st Century Skills: Rethinking How Students Learn. Ed. J. Bellanca ve R. Brandt. Bloomington IN: Solution Tree Press. 51-75.

Demircan, Ömer (2005). "Söz Dizimine Duygusal Yansımalar: Atasözleri, Deyimler, Deyimler ve Devrik Dizim”. Türk Dili Dergisi 18 (107): 1-11.

Dik, Tuba (2010). "Atasözlerinde Adil Dünya İnancı". Millî Folklor 88: 28-32.

Dosi, Ifigeneia (2019). "Do Proverbs Measure Abstract or Metaphorical Thinking:

Evidence From Healthy Greek-Speaking Adults". European Journal of Psychological Research 6(1): 75-83.

Dundes, Alen (1975). "On The Structure of The Proverb". Proverbium 25: 961973.

Erginer, Güzide (2010). Atasözlerinde Toplumsal Hayat. Yüksek Lisans Tezi. Hatay: Mustafa Kemal Üniversitesi.

Eryılmaz, Selami ve Çelebi Uluyol (2015). "21. Yüzyıl Becerileri Işı̆̆ında FATİH Projesi Değerlendirmesi”. Gazi Eğitim Fakültesi Dergisi 35 (2): 209-229.

Esen, Saban ve Ensar Yılmaz (2011). "Türk Atasözleri ve Deyimlerinde Girişimcilik

Olgusu (Sosyo-Ekonomik Açıdan Bir Bakış)”. Dumlupınar Üniversitesi Sosyal Bilimler Dergisi 30: 249-258.

Fullan, Michael (2013). "Great to Excellent: Launching the Next Stage of Ontario's Education Agenda”. http://www.michaelfullan.ca (Erişim Tarihi: 16 Mayıs 2018).

Girmen, Pınar (2016). “Türkçe Eğitiminde Atasözleri ve Değer Eğitimi”. Değerler Eğitimi Dergisi 11 (25): 117-142.

Gönen, Sinan (2006). Batı Türklerinin Manzum Atasözleri Üzerine Bir Araşttrma. 
Doktora Tezi. Konya: Selçuk Üniversitesi.

Gürel, Emeti ve Merba Tat (2012). "Bir İletişim Edimi Olarak Dinleme ve Türkçede Bulunan Dinleme Temalı Atasözleri ile Deyimler Üzerine Bir İçerik Analizi”. Uluslararası Sosyal Araştırmalar Dergisi 5 (23): 276-297.

Güzel, Abdurrahman ve Özay Karadağ (2013). "Kelime Sıklığı Açısından Türk Atasözleri Üzerine Bir Değerlendirme”. Mersin Üniversitesi Eğitim Fakültesi Dergisi 9 (1): 274-280.

Harbi, Kübra ve Özlem Yaşar Uğurlu (2018). “Girişimcilik Olgusunun Türk Atasözlerinde İçerik Analizi Yöntemiyle İncelenmesi”. Mustafa Kemal Üniversitesi Sosyal Bilimler Enstitüü̈ Dergisi 15 (41): 128-146.

Honeck, Richard P. ve Jon G. Temple (1994). "Proverbs: The Extended Conceptual Base and Great Chain Metaphor Theories". Metaphor and Symbolic Activity 9 (2): 85-112.

Karadağ, Özay (2013a). "Türkiye Türkçesi Atasözlerinde Çocuk ve Çocukluk”. Millî Folklor 98: 109-124.

Karadağ, Özay (2013b). "Emotional Intelligence Functions of Turkish Proverbs". Social Behavior and Personality: An International Journal 41 (2): 295-310.

Keklik, Sadettin (2013). "Atasözleri Sadece Gerçek ve Mecaz Anlamlı mıdır?”. Mustafa Kemal Üniversitesi Sosyal Bilimler Enstitüsü Dergisi 23: 239-250.

Keser, Nilüfer ve Voltan-Acar, Nilüfer (2013). “Türk Atasözlerinde Bilişsel Çarpitmalar”. Akademik Bakıs Dergisi 35: 1-20.

Kurt, İhsan (2012). Türk Atasözlerine Psikolojik Yaklaşımlar. Ankara: Akçağ Yayınları.

Küçük, Orhan (2015). "Halk Kültüründe Girişimcilik: Atasözleri Üzerinde Bir Araştırma”. The International New Issues In Social Sciences 1 (1): 7-20.

Mac Coinnigh, Marcas (2015). "5 Structural Aspects of Proverbs". In Introduction to Paremiology: A Comprehensive Guide to Proverb Studies. Ed. HrisztovaGotthardt, H. ve Varga, M.A. Berlin, Boston: De Gruyter. 112-132.

Mieder, Wolfgang (2010). "American Proverbs: An International, National, and Global Phenomenon". Western Folklore 69 (1): 35-54.

Mumford, Michael D. vd. (2018) "Creative Thinking in The Real World". The Nature of Human Creativity. Ed. Robert J. Sternberg ve James C. Kaufman. 147-165.

MYK (Mesleki Yeterlilik Kurumu). “Türkiye Yeterlilikler Çerçevesi”. https://www. myk.gov.tr/ (Erişim Tarihi: 8 Mayıs 2020).

Onan, Bilginer (2011). “Türk Atasözlerinde Dil Farkındalığı ve İşlevsel Dil Kullanımı”. Millî Folklor 23 (91): 90-100.

Örge Yaşar, F. (2007). "Bilgi Toplumu Bağlamında Türk Atasözlerinde "Eğitim” ve "Bilgi” Kavramları Üzerine Düşünceler”. Elektronik Sosyal Bilimler Dergisi 
6 (19): 146-158.

P21 (Partnership for 21st Century Learning). "Framework for 21st Century Learning”. http://www.p21.org/ (Erişim Tarihi: 5 Haziran 2018).

Ravitz, Jason vd. (2012). "Using Project Based Learning to Teach 21st Century Skills: Findings from a Statewide Initiative". Conference of American Educational Research Association. Vancouver. BC. 1-9.

Rong, Hou (2013). "Proverbs Reveal Culture Diversity". Cross-Cultural Communication 9 (2): 31-35.

Sternberg, Robert J. ve Todd I. Lubart (1999). "The Concept of Creativity: Prospects and Paradigms”. Handbook of Creativity. Ed. Robert J. Sternberg. Cambridge, England: Cambridge University Press. 3-15

Tekşan, Keziban (2012). "Atasözlerinin Dil Bilgisi Öğretiminde Kullanılabilirliği”. Türklük Bilimi Araştırmaları 31: 301-322.

Trilling, Bernie ve Charles Fadel (2012). 21st Century Skills: Learning for Life in Our Times. San Francisco: Jossey-Bass.

Tuğluk, Mehmet Emin (2018). “Atasözlerinde Cümle Türleri”. Mecmua Uluslararası Sosyal Bilimler Dergisi 3 (5): 26-47.

Tüm, Gülden (2010). “Atasözlerinin Değişik Kültür ve Dilleri Anlamadaki Rolü”. Turkish Studies, International Periodical For the Languages, Literature and History of Turkish or Turkic 5 (4): 663-678.

Türk Dil Kurumu (2018). “Güncel Türkçe Sözlük”. https://sozluk.gov.tr/ (Erişim Tarihi: 1 Mays 2020).

Van Lancker, Diana (1990). "The Neurology of Proverbs". Behavioral Neurology 3: 169-187.

Yin, Robert K. (2017). Durum Çalışması Araştırması Uygulamaları. Çev. İlhan Günbayı. Ankara: Nobel Yayınevi. 


\title{
A Glance From The 21th Century Skills Framework To Turkish Proverbs
}

\begin{abstract}
The concept of the universe, the thought system and the proverbs that reveal the perspective of the world are concrete reflections of collective consciousness. The mentioned language treasure also has the function of moving some of the teachings that regulate the social life of the individual within the the culture in which he/she exists beyond time and place. In this framework, it also advises future generations with the function of transferring the codes of the culture it is in. In this study, Turkish proverbs have been examined in terms of 21 st century skills (creativity and innovation, critical thinking and problem solving, communication, collaboration) which are desired from the modern man of our age. The study object of this research, which uses case study from qualitative research designs, consists of 18837 proverbs taken from Turkish Proverbs of Nurettin Albayrak's. Document analysis was used to collect the data, and content analysis was used to analyze the data. As a result of the study, it was determined that the critical thinking and problem solving skills were emphasized mostly in Turkish proverbs. Critical thinking and problem solving are followed by communication, collaboration and creativity skills respectively.
\end{abstract}

\section{Keywords}

Proverb, critical thinking, creative thinking, communication, collaboration. 